$\begin{array}{r}\text { Phinisi Integration Review } \\ \text { Vol. 2, No.1, Februari 2019 Hal 91-99 } \\ \text { Website: http://ojs.unm.ac.id/pir } \\ \text { p-ISSN: 2614-2325 dan e-ISSN: 2614-2317 } \\ \hline\end{array}$

\title{
Pengaruh Masa dan Pengalaman Mengajar terhadap Kompetensi Sosial Dosen PIP Makassar
}

\author{
Jumardin \\ Politektik Ilmu Pelayaran Makassar \\ Email: jumardin@gmail.com
}

\begin{abstract}
Abstrak. Penelitian ini bertujuan untuk mengetahui pengaruh masa mengajar dan pengalaman mengajar terhadap kompetensi sosial Dosen PIP Makassar. Metode penelitian ini adalah Metode penelitian adalah expo fakto dengan menggunakan instrument yaitu instrumen untuk menjaring data-data dosen dan instrumen untuk mengukur kompetensi sosial dosen dengan analisis deskriptif, homogenitas varians, analisis anova, dan Homogeneous subsets. Hasil penelitian ini adalah masa mengajar mempengaruhi kompetensi dosen, yang terdiri tiga kelompok masa mengajar mempengaruhi tingkat kompetensi dosen PIP Makassar yaitu 5 tahun dan antara 5-10 tahun serta masa mengajar di atas 10. Hasil analisis homogeneous subsets terhadap kelompok masa mengajar menyatakan bahwa kelompok masa mengajar kurang dari 5 tahun, antara 5-10 tahun dan di atas 10 tahun menunjukkan secara nyata perbedaan dalam pencapaian kompetensi dosen secara umum yaitu semakin besar pengalaman dan masa mengajar maka semakin besar kompetensi sosial yang dimiliki dosen.
\end{abstract}

Kata Kunci: Masa mengajar; pengalaman Mengajar; dan Kompetensi sosial

Abstract. This study aims to determine the effect of teaching period and teaching experience on the social competence of Makassar PIP Lecturers. The method of this research is the research method is expo facto using instruments, namely instruments to capture lecturer data and instruments to measure lecturers' social competencies with descriptive analysis, variance homogeneity, ANOVA analysis, and Homogeneous subsets. The results of this study are that the teaching period influences the competence of lecturers, which consists of three teaching periods affecting the competency level of Makassar PIP lecturers which is 5 years and between 5-10 years and the teaching period is above. teaching less than 5 years, between 5 - 10 years and over 10 years shows a significant difference in the achievement of lecturer competencies in general, namely the greater the experience and period of teaching, the greater the social competence of the lecturer.

Keywords: Teaching period; teaching experience; and social competence

Ini adalah artikel dengan akses terbuka dibawah licenci CC BY-NC-4.0 (https://creativecommons.org/licenses/by-nc/4.0/).

\section{PENDAHULUAN}

Kompetensi sebagai suatu kemampuan menjadi bagian terpenting dalam meningkatkan kinerja.peningkatan kinerja pada instansi harus menjadi faktu utama dalam meningkatkan kualitas pekerjaan. Kompetensi merupakan penguasaan terhadap merupakan tugas, keterampilan, sikap dan apresiasi yang diperlukan untuk menunjang keberhasilan (Mulyana, 2005). Komptensi dalampersepsi lain, secara profesional berkaitan dengan keterampilan, kecerdasan dan nilai di masyarakat Mama (Kirby et al. 2019; Jumardin 2018; Eigenbrode. 2007). Kompetensi dipandang dari aspek pribadi merupakan seorang pekerja yang memungkinkan dia untuk mencapai kinerja yang 
superior, (LOMA.s Dictionary,1998). Dosen sebagai tenaga pendidik dituntut harus menguasai dan memiliki kompetensi, salah satunya kompetensi sosial. Kompetensi sosial dosen merupakan kemampuan seorang guru dan dosen untuk berkomunikasi dan berinteraksi secara efektif dan efisien dengan peserta didik, guru, orang tua, dan masyarakat sekitar. kompetensi sosial sebagai konstruk dinamis yang melibatkan kemampuan untuk menyesuaikan diri dan berinteraksi dalam kondisi sosial (Argyle, 1994; Tajfel, 1981) Kompetensi sosial terdiri dari interaksi antara karakteristik individu, tuntutan sosial, dan karakteristik situasional (Hoermann and Goerke 2014).

Kompetensi sosial yang harus dimiliki oleh seorang pendidik yang diamanatkan oleh UU Guru dan Dosen, yang pada gilirannya harus dapat ditularkan kepada anak-anak didiknya. Untuk mengembangkan kompetensi sosial seorang pendidik dapat berubaha jika dilihat sejauh mana keadaan sosial yang telah di jalani seoran pendidik terutama dari masa mengajarnya. Masa mengajar akan merubah sikap dan tingkah laku sesorang khususnya dalam bersosial kepada orang lain baik mahasiswa maupun dosen dalam lingkup kampus.

Pengalaman mengajar yang diperoleh seorang dosen di masa lampau dapat menjadikan mereka pembelajaran yang akan datang, sejalan dengan ungkapan yang menyatakan bahwa pengalaman merupakan guru yang paling baik. Hal ini sejalan dengan pendapat Robbin (1990) yang menyatakan bahwa pengalamanpengalaman yang pernah dialami, seseorang akan dapat mengimplementasikan pengalaman baru dengan berdasar pada pengalaman lampau. Andinta, Erlinayanti (2012) dalam penelitiannya menyatakan bahwa selain latar belakang pendidikan mempengaruhi kompetensi dosen, pengalaman pengajar juga dapat mempengaruhi kompetensi seorang pendidik. Politeknik Ilmu Pelayaran sebagai lembaga pendidikan penghasil taruna atau sarjana dituntut untuk mampu menghasilkan kompetensi tenaga dosen yang baik yang dapat dilihat dari masa mengajar dan pengalaman mengajarnya pada kompetensi sosialnya. Melihat latar belaang tersebut maka peneliti tertarik untuk meneliti tentang pengaruh kompetensi soial terhadap masa dan pengalaman mengajar dosen PIP Makassar.

\section{METODE}

Jenis Penelitian ini adalah ex post facto, dengan kajian masa mengajar Dosen yang telah dilaksanakan oleh dosen terhadap peningkatan kompetensi Dosen PIP. Populasi penelitian ini adalah dosen politeknik Ilmu Pelayaran (PIP) Makassar, baik sebagai dosen bidang studi nautika sebanyak 34 orang, bidang studi teknika sebanyak 31 orang dan bidang studi sosial/eksakta sebanyak 48 orang dengan jumlah dosen menjadi populasi sebanyak 113 orang. Dengan sampel sebanyak 86 diambil dengan teknik proporsional random sampling yaitu sampel diambil secara acak dan

Teknik pengumpulan data yang digunakan menggunakan instrumen. Jenis instrumen dalam penelitian ini, yaitu: instrumen untuk menjaring data-data dosen dan instrumen untuk mengukur kompetensi sosial dosen. Instrumen untuk menjaring data-data kompetensi dosen dikembangkan dengan indikator capaian sebagai berikut: Untuk menjaring data tingkat kompetensi sosial Dosen Politeknik Ilmu pelayaran (PIP) Makassar digunakan instrumen yang diberikan kepada taruna yang diajar oleh dosen yang menjadi anggota sampel penelitian. Hal ini dimaksudkan untuk menggali data tentang kemampuan dosen mengelola proses belajarmengajar.

Instrumen kompetensi dosen ini akan dijabarkan dalam bentuk angket dengan menjabarkan beberapa pertanyaan dan menggunakan skala $1-5$. Untuk itu skor dari variabel tingkat kompetensi Sosial dosen ini dapat diwujudkan dalam bentuk angka yang merupakan rata-rata dari taruna yang memberikan penilaian. Berikut ini aspek dan indikator instrumen kompetensi sosial dosen PIP Makassar. 
Tabel 3.6 Aspek dan Indikator Instrumen Kompetensi Sosial Dosen PIP Makassar

\begin{tabular}{ll}
\hline \multicolumn{1}{c}{ Aspek } & \multicolumn{1}{c}{ Indikator } \\
\hline Objektif & Bersikap inklusif, bertindak objektif \\
Empati & Mampu berkomunikasi secara empatik, \\
& dan santun \\
Beradaptasi & Mampu beradaptasi di tempat bertugas \\
Komunitas profesi & Mampu berkomunikasi dengan \\
& komunitas profesi \\
\hline
\end{tabular}

Pengumpulan data dalam penelitian ini menggunakan instrumen berbentuk angket dan rating scale. Angket dalam penelitian ini digunakan untuk mengumpulkan data variabel tingkat pendidikan, pengalaman mengajar dan pengalaman berlayar. Untuk menjaring data tingkat kompetensi pedagogik, profesional, keperibadian dan sosial dosen Politeknik Ilmu pelayaran (PIP) Makassar digunakan rating scale.

\section{HASIL DAN PEMBAHASAN}

\section{Masa mengajar dan kompetensi sosial}

Hasil analisis penelitian antara masa mengajar dosen PIP dengan kompetensi sosial dengan menggunakan aplikasi SPSS menampilkan hasil analisis deskriptif, homogenitas varians, analisis anova, dan Homogeneous subsets, berikut ini pemaparan hasil analisis aplikasi SPSS tersebut.

a. Analisis deskriptif

Hasil analisis deskriptif antara masa mengajar dengan kompetensi sosial dosen PIP Makassar ditunjukkan pada Tabel 5.32.

Tabel 5.32 Analisis Deskriptif antara Masa Mengajar dengan Kompetensi Sosial Dosen PIP Makassar

\begin{tabular}{cccccc}
\hline Masa Berlayar & \multirow{2}{*}{ N } & Skor & Std. & \multicolumn{2}{c}{ Skor } \\
\cline { 5 - 6 } & & Rata-rata & Deviasi & Minimal & Maksimal \\
\hline$<5$ Thn & 28 & 3,99 & 0,44 & 2,76 & 4,65 \\
$5-10$ Thn & 18 & 3,79 & 0,48 & 2,98 & 4,69 \\
$>10$ Thn & 40 & 3,97 & 0,41 & 3,19 & 4,69 \\
\hline Jumlah & 86 & 3,93 & 0,44 & 2,76 & 4,69 \\
\hline
\end{tabular}

Dari hasil analisis data terlihat bahwa masa mengajar kurang dari 5 tahun diperoleh skor rata-rata sebesar 3,99 dengan standar deviasi sebesar 0,44, skor minimal sebesar 2,76, dan skor maksimal sebesar 4,65, untuk masa mengajar antara 5-10 tahun diperoleh skor rata-rata sebesar 3,79 dengan standar deviasi sebesar 0,48, skor minimal sebesar 2,98, dan skor maksimal sebesar 4,69, sedangkan untuk masa mengajar di atas 10 tahun diperoleh skor rata-rata sebesar 3,97 dengan standar deviasi sebesar 0,41 , skor minimal sebesar 3,19, dan skor maksimal sebesar 4,69 .

Dalam bentuk grafik hasil analisis skor rata-rata kompetensi sosial dosen PIP Makassar ditinjau pada masa kerja mengajar kurang dari 5 tahun, antara 5-10 tahun dan lebih dari 10 tahun, disajikan pada Gambar 5.8. 


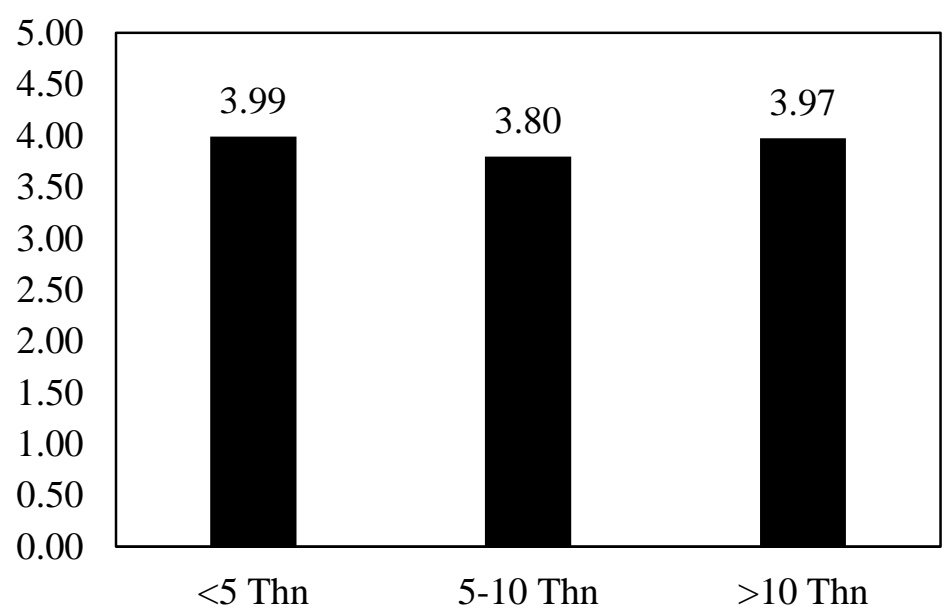

Gambar 5.8 Skor Rata-rata Kompetensi Sosial berdasarkan Masa Mengajar Dosen PIP Makassar

a. Analisis homogenitas varians

Hasil analisis homogenitas variansi antara masa mengajar dengan kompetensi sosial dosen PIP Makassar ditunjukkan pada Tabel 5.33.

Tabel 5.33 Hasil Analisis Homogenitas variansi antara Masa Mengajar dengan Kompetensi Sosial Dosen PIP Makassar

\begin{tabular}{cccr}
\hline $\begin{array}{c}\text { Levene } \\
\text { Statistic }\end{array}$ & df1 & df2 & $\begin{array}{c}\text { Signifi } \\
\text { kansi }\end{array}$ \\
\hline 0,48 & 2 & 83 & 0,62 \\
\hline
\end{tabular}

Untuk menguji hasil analisis homogenitas variansi diajukan hipotesis, sebagai berikut:

$\mathrm{H}_{0}$ : Ketiga varian populasi adalah identik (homogen)

$\mathrm{H}_{\mathrm{a}}$ : Ketiga varian tidak identik

Dari analisis Test of Homogenity of variances dapat diketahui bahwa besarnya angka Levene Statistic adalah 0,48 sedangkan probabilitas atau signifikansinya adalah 0,62. Nilai probabilitas sebesar 0,62 lebih besar dari nilai taraf signifikansi $0,05(5 \%)$, yang berarti hipotesis nihil $\left(\mathrm{H}_{0}\right)$ diterima dan menolak hipotesis alternatif $\left(\mathrm{H}_{\mathrm{a}}\right)$, sehingga disimpulkan bahwa ketiga varian populasi adalah identik (homogen).

b. Analisis anova

Hasil analisis anova antara masa mengajar dengan kompetensi Sosial dosen PIP Makassar ditunjukkan pada Tabel 5.34.

Tabel 5.34 Hasil Analisis Anova antara Masa Mengajar dengan Kompetensi Sosial Dosen PIP Makassar

\begin{tabular}{|c|c|c|c|c|}
\hline Sumber Variansi & $\begin{array}{l}\text { Sum of } \\
\text { Squares }\end{array}$ & f & $\begin{array}{c}\text { Mea } \\
\text { n Square }\end{array}$ & g. $\quad$ Si \\
\hline Antar kelompok & 0,57 & & 0,28 & $3^{0,2}$ \\
\hline Dalam kelompok & 16,05 & 3 & 0,19 & \\
\hline Total & 16,62 & 5 & & \\
\hline
\end{tabular}


Untuk menguji hasil analisis anova diajukan hipotesis, sebagai berikut:

$\mathrm{H}_{0}$ : Tidak ada perbedaan kompetensi sosial antara masa mengajar kurang dari 5 tahun, antara 5 - 10 tahun dan lebih dari 10 tahun.

$\mathrm{H}_{\mathrm{a}}$ : Ada perbedaan kompetensi sosial antara masa mengajar kurang dari 5 tahun, antara 5- 10 tahun, dan lebih dari 10 tahun

Untuk menguji hipotesis yang diajukan di atas dilakukan berdasarkan nilai probabilitas atau signifikansi hasil analisis aplikasi SPSS. Tabel anova di atas menunjukkan bahwa besarnya nilai probabilitas atau signifikansinya sebesar 0,23 lebih besar dari 0,05 dengan demikian hipotesis nihil $\left(\mathrm{H}_{0}\right)$ diterima dan menolak $\mathrm{H}_{\mathrm{a}}$ (hipotesis alternatif). Hal ini menunjukkan bahwa tidak ada perbedaan nyata kompetensi sosial antara masa mengajar kurang dari 5 tahun, antara 5 - 10 tahun dan lebih dari 10 tahun. Harena hasil analisi menunjukkan tidak ada perbedaan maka analisis untuk menentukan kelompok yang berbeda melalui analisis homogeneous subsets tidak perlu dilakukan.

\section{Analisis komparasi multivariate antara kelompok masa mengajar dengan kompetensi dosen}

\section{a. Analisis homogenitas varians}

Hasil analisis homogenitas varians antara kelompok masa mengajar dengan kompetensi dosen PIP Makassar ditunjukkan pada Tabel 5.35.

Tabel 5.35 Hasil Analisis Homogenitas variansi antara Masa Mengajar dengan Kompetensi Dosen PIP Makassar

\begin{tabular}{ccccc}
\hline F & df1 & df2 & $\begin{array}{c}\text { Signifi } \\
\text { kansi }\end{array}$ \\
\hline 3.23 & 11 & $2^{33}$ & 0.00 \\
\hline
\end{tabular}

Untuk menguji hasil analisis homogenitas variansi diajukan hipotesis, sebagai berikut:

$\mathrm{H}_{0}$ : Varian variabel terikat adalah identik (homogen)

$\mathrm{H}_{\mathrm{a}}$ : Varian variabel terikat adalah tidak identik (heterogen)

Dari analisis Test of Homogenity of variances dapat diketahui bahwa besarnya angka Levene Statistic adalah 3,23 sedangkan probabilitas atau signifikansinya adalah 0,00 . Nilai probabilitas sebesar 0,00 lebih kecildari nilai taraf signifikansi $0,05(5 \%)$, yang berarti hipotesis nihil $\left(\mathrm{H}_{0}\right)$ diterima dan menolak hipotesis alternatif $\left(\mathrm{H}_{\mathrm{a}}\right)$, sehingga disimpulkan bahwa varian variabel terikat adalah identik (homogen), sehingga analisis komparasi multivariate dapat dilanjutkan.

b. Analisis uji pengaruf (efek)

Hasil analisis uji pengaruh (efek) diperoleh dari hasil analisis multivariate dengan test of between-subjects effect antara kelompok masa mengajar dengan kompetensi dosen PIP Makassar ditunjukkan pada Tabel 5.36.

Tabel 5.36 Hasil Analisis Test of Between-Subjects Effectantara Masa Mengajar dengan Kompetensi Dosen PIP Makassar

\begin{tabular}{cccccc}
\hline Source & $\begin{array}{c}\text { Type III Sum of } \\
\text { Squares }\end{array}$ & df & Mean Square & F & Sig. \\
\hline Corrected Model & $30.599^{\mathrm{a}}$ & 11 & 2.782 & 17.884 & .000 \\
Intercept & 5218.601 & 1 & 5218.601 & $3.355 \mathrm{E} 4$ & .000 \\
Masa Mengajar & 10.386 & 2 & 5.193 & 33.385 & .000 \\
Kompetensi & 6.821 & 3 & 2.274 & 14.617 & .000 \\
Mengajar * Kompetensi & 13.796 & 6 & 2.299 & 14.782 & .000 \\
Error & 51.640 & 332 & .156 & & \\
Total & 5560.829 & 344 & & & \\
Corrected Total & 82.239 & 343 & & & \\
\hline
\end{tabular}


1) Uji pengaruh kelompok masa mengajar terhadap kompetensi dosen

Untuk menguji pengaruh kelompok masa mengajar terhadap kompetensi dosendigunakan hasil analisis Test of Between-Subjects Effect, dengan sebelumnya diajukan hipotesis, sebagai berikut:

$$
\begin{aligned}
& \mathrm{H}_{0} \text { : Masa mengajar tidak } \\
& \text { mempengaruhi tingkat kompetensi } \\
& \text { dosen PIP Makassar } \\
& \mathrm{H}_{\mathrm{a}}: \text { Masa mengajar mempengaruhi } \\
& \text { tingkat kompetensi dosen PIP } \\
& \text { Makassar }
\end{aligned}
$$

Dari analisis Test of Between-Subjects Effect (tabel 5.36) dapat diketahui bahwa besarnya $\mathrm{F}$ ratio ( $\mathrm{F}$ hitung) untuk faktor masa mengajar sebesar 33,38 dengan mengkonfirmasikan nilai $\mathrm{F}$ hitung $=33,38$ dengan $\mathrm{F}$ tabel dengan taraf signifikansi 0,05 (5\%) dengan $\mathrm{dk}$ untuk pembilang $2 \mathrm{dan} \mathrm{dk}$ penyebut 332 diperoleh $\mathrm{F}$ tabel sebesar 3,02, maka terlihat bahwa F hitung $(33,38)$ lebih besar dibanding dengan $\mathrm{F}$ tabel $(3,02)$ yang berarti hipotesis alternatif $\left(\mathrm{H}_{\mathrm{a}}\right)$ yang berbunyi "masa mengajar mempengaruhi tingkat kompetensi dosen PIP Makassar" diterima untuk taraf signifikansi 5\% dan hipotesis nihil $\left(\mathrm{H}_{0}\right)$ yang berbunyi "masa mengajar tidak mempengaruhi tingkat kompetensi dosen PIP Makassar" ditolak.

Hal ini berarti bahwa masa mengajar mempengaruhi kompetensi dosen, setidaknya dari tiga kelompok masa mengajar mempengaruhi tingkat kompetensi dosen PIP Makassar. Akan tetapi sampai pada taraf ini belum dapat dipastikan kelompok masa mengajar yang mana yang benar-benar mempengaruhi tingkat kompetensi dosen. Dalam hal ini ada beberapa kemungkinan yang terjadi, yaitu:

1. Kelompok masa mengajar kurang dari 5 tahun dan antara 5-10 tahun sama-sama mempengaruhi tingkat kompetensi dosen sedangkan kelompok masa mengajar di atas 10 tahun tidak mempengaruhi.

2. Kelompok masa mengajar kurang dari 5 tahun tidak mempengaruhi tingkat kompetensi dosen sedangkan kelompok masa mengajar antara 5-10 tahun dan di atas 10 tahun berpengaruh.

3. Kelompok masa mengajar antara 5-10 tahun tidak berpengaruh terhadap tingkat kompetensi dosen, sedangkan kelompok masa mengajar kurang dari 5 tahun dan di atas 10 tahun berpengaruh.
4. Kelompok masa mengajar kurang dari 5 tahun, antara 5-10 tahun dan di atas 10 tahun berpengaruh terhadap tingkat kompetensi dosen.

2) Uji pengaruh kelompok kompetensi dosen terhadap kompetensi dosen secara umum

Untuk menguji pengaruh kelompok kompetensi dosen terhadap kompetensi dosen secara umum digunakan hasil analisis Test of Between-Subjects Effect, dengan sebelumnya diajukan hipotesis, sebagai berikut:

$\mathrm{H}_{0}$ : Kelompok kompetensi dosen tidak mempengaruhi tingkat kompetensi dosen PIP Makassar

$\mathrm{H}_{\mathrm{a}}$ : Kelompok kompetensi dosen mempengaruhi tingkat kompetensi dosen PIP Makassar

Dari analisis Test of Between-Subjects Effect (tabel 5.36) dapat diketahui bahwa besarnya $\mathrm{F}$ ratio (F hitung) untuk faktor kelompok kompetensi dosen sebesar 14,62, dengan mengkonfirmasikan nilai $\mathrm{F}$ hitung $=$ 14,62 dengan $\mathrm{F}$ tabel dengan taraf signifikansi 0,05 (5\%) dengan dk untuk pembilang $3 \mathrm{dan} \mathrm{dk}$ penyebut 332 diperoleh $\mathrm{F}$ tabel sebesar 2,63, maka terlihat bahwa F hitung $(14,62)$ lebih besar dibanding dengan $\mathrm{F}$ tabel $(2,63)$ yang berarti hipotesis alternatif $\left(\mathrm{H}_{\mathrm{a}}\right)$ yang berbunyi "kelompok kompetensi dosen mempengaruhi tingkat kompetensi dosen PIP Makassar" diterima untuk taraf signifikansi 5\% dan hipotesis nihil $\left(\mathrm{H}_{0}\right)$ yang berbunyi "kelompok kompetensi dosen tidak mempengaruhi tingkat kompetensi dosen PIP Makassar" ditolak.

Hal ini berarti bahwa kelompok kompetensi dosen mempengaruhi kompetensi dosen PIP Makassar, setidaknya dari empat kelompok kompetensi dosen mempengaruhi tingkat kompetensi dosen PIP Makassar. Akan tetapi sampai pada taraf ini belum dapat dipastikan kelompok kompetensi dosen yang mana yang benar-benar mempengaruhi tingkat kompetensi dosen.

3) Uji pengaruh kelompok masa mengajar dan kelompok kompetensi dosen terhadap kompetensi dosen secara umum

Untuk menguji pengaruh kelompok masa mengajar dan kelompok kompetensi dosen terhadap kompetensi dosensecara umum 
digunakan hasil analisis Test of Between-Subjects Effect, dengan sebelumnya diajukan hipotesis, sebagai berikut:

$\mathrm{H}_{0}$ : Tingkat kompetensi dosen PIP Makassar karena kelompok masa mengajar tidak bergantung pada kelompok kompetensi dosen dan tingkat kompetensi dosen PIP Makassar karena kelompok kompetensi dosen tidak bergantung pada kelompok masa mengajar.

$\mathrm{H}_{\mathrm{a}}$ : Tingkat kompetensi dosen PIP Makassar karena kelompok masa mengajar bergantung pada kelompok kompetensi dosen dan tingkat kompetensi dosen PIP Makassar karena kelompok kompetensi dosen bergantung pada kelompok masa mengajar.

Dari analisis Test of Between-Subjects Effect (tabel 5.36) dapat diketahui bahwa besarnya $\mathrm{F}$ ratio ( $\mathrm{F}$ hitung) untuk faktor kelompok masa mengajar dan kelompok kompetensi dosen sebesar 14,78, dengan mengkonfirmasikan nilai $\mathrm{F}$ hitung $=14,78$ dengan $\mathrm{F}$ tabel dengan taraf signifikansi 0,05 (5\%) dengan $\mathrm{dk}$ untuk pembilang $6 \mathrm{dan} \mathrm{dk}$ penyebut 332 diperoleh $\mathrm{F}$ tabel sebesar 2,12, maka terlihat bahwa F hitung $(14,78)$ jauh lebih besar dibanding dengan $\mathrm{F}$ tabel $(2,12)$ yang berarti hipotesis alternatif $\left(\mathrm{H}_{\mathrm{a}}\right)$ yang berbunyi "tingkat kompetensi dosen PIP Makassar karena kelompok masa mengajar bergantung pada kelompok kompetensi dosen dan tingkat kompetensi dosen PIP Makassar karena kelompok kompetensi dosen bergantung pada kelompok masa mengajar" diterima untuk taraf signifikansi $5 \%$ dan hipotesis nihil $\left(\mathrm{H}_{0}\right)$ yang berbunyi "tingkat kompetensi dosen PIP Makassar karena kelompok masa mengajar tidak bergantung pada kelompok kompetensi dosen dan tingkat kompetensi dosen PIP Makassar karena kelompok kompetensi dosen tidak bergantung pada kelompok masa mengajar" ditolak.

\section{c. Analisis post hoc test}

Analisis post hoc test dilakukan untuk mengetahui kelompok mana yang berbeda dan mana yang tidak. Hasil analisis post hoc test ditampilkan pada Tabel 5.37 di bawah ini.

Tabel 5.37 Hasil Analisis post hoc Test antara Masa Mengajar dengan Kompetensi Dosen PIP Makassar

\begin{tabular}{|c|c|c|c|c|c|c|c|}
\hline & \multirow{2}{*}{$\begin{array}{c}(\mathrm{I}) \\
\text { Kelompok } \\
\text { masa } \\
\text { mengajar }\end{array}$} & \multirow{2}{*}{$\begin{array}{c}\mathbf{( J )} \\
\text { Kelompok } \\
\text { masa } \\
\text { mengajar }\end{array}$} & \multirow{2}{*}{$\begin{array}{c}\text { Mean } \\
\text { Differen } \\
\text { ce }(\mathbf{I}-\mathbf{J})\end{array}$} & \multirow[b]{2}{*}{$\begin{array}{l}\text { Std. } \\
\text { Error }\end{array}$} & \multirow[b]{2}{*}{ Sig. } & \multicolumn{2}{|c|}{$\begin{array}{l}\text { 95\% Confidence } \\
\text { Interval }\end{array}$} \\
\hline & & & & & & $\begin{array}{l}\text { Lower } \\
\text { Bound }\end{array}$ & $\begin{array}{l}\text { Upper } \\
\text { Bound }\end{array}$ \\
\hline \multirow[t]{6}{*}{ Tukey HSD } & \multirow{2}{*}{$<5$ Thn } & 5-10 Thn & $-.2310^{*}$ & .05618 & .000 & -.3633 & -.0988 \\
\hline & & $>10 \mathrm{Thn}$ & $-.4060^{*}$ & .04969 & .000 & -.5230 & -.2890 \\
\hline & \multirow{2}{*}{ 5-10 Thn } & $<5 \mathrm{Thn}$ & $.2310^{*}$ & .05618 & .000 & .0988 & .3633 \\
\hline & & $>10 \mathrm{Thn}$ & $-.1750^{*}$ & .05336 & .003 & -.3006 & -.0493 \\
\hline & \multirow{2}{*}{$>10 \mathrm{Thn}$} & $<5 \mathrm{Thn}$ & $.4060^{*}$ & .04969 & .000 & .2890 & .5230 \\
\hline & & 5-10 Thn & $.1750^{*}$ & .05336 & .003 & .0493 & .3006 \\
\hline
\end{tabular}

Dari tabel 5.37 di atas dapat dilihat perbedaan mean kelompok masa mengajar kurang dari 5 tahun dengan kelompok masa mengajar 5-10 tahun adalah -0.23 (kelompok masa mengajar kurang 5 tahun lebih kecil sebanyak 0,23 poin dibanding kelompok masa mengajar 5-10 tahun). Perbedaan mean kelompok masa mengajar kurang 5 tahun dengan kelompok masa mengajar di atas 10 tahun adalah $-0,40$ (kelompok masa mengajar kurang 5 tahun lebih kecil sebanyak 0,40 poin dibanding kelompok masa mengajar di atas 10 tahun). Perbedaan mean kelompok masa mengajar antara 5 - 10 tahun dengan kelompok masa mengajar di atas 10 tahun adalah $-0,17$ (kelompok masa mengajar antara 5-10 tahun lebih besar sebanyak 0,17 poin dibanding kelompok masa mengajar di atas 10 tahun).

d. Analisis homogeneous subsets

1) Analisis homogeneous subset berdasarkan kelompok masa mengajar

Analisis homogeneous subsets kelompok masa mengajar dilakukan untuk mencari atau menguji kelompok mana yang tidak berbeda secara signifikansi (perbedaan nyata) dengan kelompok lainnya. Berikut ini hasil analisis homogeneous subsets ditampilkan pada Tabel 5.38 di bawah ini. 
Tabel 5.38 Hasil Analisis homogeneous subsets berdasarkan kelompok masa mengajar

\begin{tabular}{cccccr}
\hline & $\begin{array}{c}\text { Kelompok Masa } \\
\text { Mengajar }\end{array}$ & N & \multicolumn{3}{c}{ Subset } \\
\cline { 4 - 6 } & $<5$ Thn & 112 & 3.7617 & & $\mathbf{3}$ \\
\hline Tukey HSD $^{\mathrm{a}}$ & $>10 \mathrm{Thn}$ & 88 & & 3.9927 & \\
& $5-10 \mathrm{Thn}$ & 144 & & & 4.1677 \\
& Sig. & & 1.000 & 1.000 & 1.000 \\
\hline
\end{tabular}

Dari Tabel 5.38 di atas dapat terlihat bahwa pada subset 1 terdapat kelompok masa mengajar kurang dari 5 tahun dengan skor ratarata 3,76 , sedangkan pada subsets 2 terdapat kelompok masa mengajar antara 5 - 10 tahun dengan skor rata-rata 3,99 , dan pada subsets 3 terdapat kelompok masa mengajar di atas 10 tahun, dengan skor rata-rata sebesar 4,17. Hal ini berarti bahwa pada dasarnya kelompok masa mengajar kurang dari 5 tahun, antara 5 - 10 tahun dan di atas 10 tahun menunjukkan secara nyata perbedaan dalam pencapaian kompetensi dosen secara umum.

\section{SIMPULAN DAN SARAN}

Hasil penelitian ini adalah masa mengajar mempengaruhi kompetensi dosen, yang terdiri tiga kelompok masa mengajar mempengaruhi tingkat kompetensi dosen PIP Makassar yaitu 5 tahun dan antara 5-10 tahun serta masa mengajar di atas 10. Hasil analisis homogeneous subsets terhadap kelompok masa mengajar menyatakan bahwa kelompok masa mengajar kurang dari 5 tahun, antara 5 - 10 tahun dan di atas 10 tahun menunjukkan secara nyata perbedaan dalam pencapaian kompetensi dosen secara umum yaitu semakin besar pengalaman dan masa mengajar maka semakin besar kompetensi sosial yang dimiliki dosen.

Berdasarkan hasil penelitian yang diperoleh diharapkan, kepada pada tingkat pimpinan PIP Makassar dapat mengambil kebijakan: (1) Untuk meningkatkan kompetensi sosial dosen PIP Makassar di sarankan meningkatkan interaksi baik dilingkungan kampus dengan taruna, pegawai, sesama dosen termasuk berinteraksi dengan lingkungan lainnya dengan tidak mengabaikan sistim pendidikan boarding school; (2) Untuk peneliti selanjutnya dapat mengkaji kompetensi lainnya; (3) Dengan keterbatasan penelitian ini diharapkan peneliti selanjutnya dapat menggali lebih dalam yang berkaitan dengan kompetensi dosen Politeknik Ilmu Pelayaran Makassar.

\section{DAFTAR RUJUKAN}

Argyle, M. (1994). The psychology of interpersonal behaviour (5th ed.). London, UK: Penguin.

Andinta, Erlinayanti. 2012. pengaruh latar belakang pendidikan, pengalaman mengajar dan etos kerja guru terhadap kompetensi profesional guru pkn di sma negeri di kabupaten magelang. s1 thesis, universitas negeri yogyakarta. Laporan penelitian

Eigenbrode SD, O'Rourke M, Wulfhorst JD, Althoff DM, Goldberg CS, Merrill K, et al. (2007) Employing philosophical dialogue in collaborative science. Biosci. 57(1):55-64.

Mulyana, Agung, Didik, 2005, Studi Tentang Kemampuan Kerja, Iklim Organisasi, dan Motivasi Terhadap Kualitas Pelayanan Kesehatan Di Rumah Sakit Umum Daerah Kota Semarang. Online. http://eprints.undip.ac.id/1475 0/1/img517074358.pdf

Loma Dictionary, 1998. LOMA's Competency Dictionary. Journal of the American Society of. CLU

Hoermann, Hans Juergen, and Panja Goerke. 2014. "Assessment of Social Competence for Pilot Selection." International Journal of Aviation Psychology $24 \quad$ (1): 6-28. https://doi.org/10.1080/10508414.2014. 860843.

Jumardin. 2018. "Analisis Kompetensi Pedagogik Dan Kompetensi Profesional Dosen." Indonesia Journal of Learning Education and Counseling 1 (1): 76-84.

Kirby, Caitlin K., Patricia Jaimes, Amanda R. Lorenz-reaves, and Julie C. Libarkin. 2019. "Development of a Measure to Evaluate Competence Perceptions of 
Natural and Social Science." PLoS ONE,

$1-16$.

https://doi.org/10.1371/journal.pone.020

9311.

Robbins, Stephen. 1990. Perilaku Organisasi, Jakarta : Prehalindo

Tajfel, H. (1981). Human groups and social categories. Cambridge, UK: Cambridge University Press. Science." PLOS ONE, $1-16$.

https://doi.org/10.1371/journal.pone.020 9311. 